\title{
Addressing the Sustainability Challenge: Insights from Institutional Theory and Organizational Learning
}

\author{
Juliana Iarossi \\ Coalesce Capital, LLC \\ Jeanette Miller \\ 360DegreeTD \\ James O'Connor \\ University of South Carolina Upstate \\ Mark Keil \\ Georgia State University
}

\begin{abstract}
A broad range of stakeholders is focusing on corporate sustainability, yet little is known about how individual firms respond to these institutional pressures. In this paper, institutional theory is integrated with theories of organizational learning to understand how firms shape their response through sustainability initiatives. In a case study approach, we find that organizations create diverse responses through two primary strategies: manipulation and acquiescence. Sustainability initiatives were found to entail a simultaneous process of exploring new possibilities while exploiting existing capabilities, and to be facilitated through top management support, an open approach to surfacing initiatives, and intra-and inter-organizational alliances.
\end{abstract}

\section{INTRODUCTION}

There is a growing consensus regarding the importance of corporate sustainability. The $2010 \mathrm{UN}$ Global Compact - Accenture survey, the largest study of CEOs on the topic of sustainability, found that " $93 \%$ of CEOs believe that sustainability issues will be critical to the future success of their business" (Lacy et al, 2010). These findings reinforce the results of the 2008 study conducted by KPMG that reported that $80 \%$ of the world's 250 largest companies issued stand-alone reports on corporate social responsibility (CSR), and that three-quarters of the companies surveyed publically communicate their sustainability strategy with defined objectives (KPMG International Survey of Corporate Social Responsibility Reporting 2008, 2008).

At one time considered a discretionary focus, firms are now finding that government regulation and the supply chain seek, and in many cases mandate, that they demonstrate and report their actions with respect to sustainability practices. One of the most widely publicized examples occurred in 2008 when Wal-Mart, the largest retailer in the world, announced new standards centered on sustainability practices 
for companies that want to do business with them.

While corporate executives recognize that sustainability practices are critical to the continued viability of their businesses, they are only beginning to recognize the challenge of implementing those practices. The UN Global Compact-Accenture study found that " $96 \%$ of the CEOs believe that sustainability issues should be fully integrated into the strategy and operations of a company (up from $72 \%$ in 2007)" (Lacey et al 2010). However, these same CEOs admit that the key challenge they face in driving this new era of sustainability is execution. The global executives surveyed by IBM in 2008 believed that corporate social responsibility requires "wholesale changes to the ways companies operate" (Pohle \& Hittner, 2008). However, a stunning 76\% of executives surveyed "admitted they don't understand their customers' CSR expectations well" (Pohle \& Hittner, 2008). So the question is no longer whether firms should pursue sustainability practices, but how do they integrate them into the operations of the business?

Corporate sustainability has its roots in corporate social responsibility (Kaynak \& Montiel, 2009). Following van Marrewijk (2003), we treat corporate social responsibility (CSR) as being synonymous with corporate sustainability (CS). Although references to CSR appear in business literature dating back to the 1930's, Carroll (1999) credits the 1953 publication of Social Responsibilities of the Businessman by Howard R. Bowen as the beginning of modern CSR literature. Despite many years of research, Lockett et al (2006) describe the CSR literature as being in a "continuing state of emergence...not characterized by the domination of a particular theoretical approach, assumptions and method...a field without a dominant paradigm..." Lack of consensus on a definition, as well as the rapidly changing position of this phenomenon on the corporate agenda, has been a challenge to theoretical development (Lockett et al., 2006; McWilliams et al, 2006).

For the purpose of this research, we developed the following broad definition of corporate sustainability by drawing upon several definitions that have appeared in the literature: Corporate sustainability refers to the strategies of an organization, typically considered voluntary, that simultaneously integrate social, environmental and economic dimensions into the operations of the organization and in its interactions with stakeholders (Kaynak \& Montiel, 2009; Quinn \& Dalton, 2009; van Marrewijk, 2003).

Institutional theory provides a useful lens to describe the sources of pressure that influence a firm's sustainability practice (Campbell, 2007; Haberberg, Gander, Rieple, Juan-Ignacio, \& Helm, 2007; Hahn \& Scheermesser, 2006; Husted \& Allen, 2006; Matten \& Moon, 2008). Models derived from institutional theory can be used as a framework to understand the different responses a firm adopts to transform institutional pressure into specific sustainability initiatives. In addition, organizational learning theory, which until now has had limited application to this phenomenon, may provide a complementary lens for understanding how companies execute sustainability initiatives. The goal of this research is to shed light on how institutional pressures and the attributes of a firm shape the execution of sustainability initiatives. Specifically, we address the following research questions:

RQ1: What are the dominant sources of institutional pressure for sustainability in the
firm?

RQ2: What are the primary response strategies that firms adopt to address institutional pressures for sustainability?

RQ3: What organizational learning strategies do firms adopt in the execution of sustainability initiatives?

\section{LITERATURE REVIEW}

\section{Strategic Perspective}

Corporate sustainability literature attempts to identify drivers and create typologies of firms based on 
the degree, type of engagement, and nature of the business environment (Haberberg et al., 2007). Some researchers have suggested that CS should be connected to the firm's mission and have emphasized the importance of managing CS strategically instead of as disparate ad hoc activities (Husted \& Allen, 2006; Porter \& Kramer, 2006). According to Husted and Allen (2006), firms that do not manage CS strategically may face serious economic consequences. Porter and Kramer (2006) recommend that analyzing CS strategically "can be a source of opportunity, innovation, and competitive advantage." Building on the literature that addresses CS as a business strategy is the greatest potential for practical application.

\section{Framework Based on Organizational Theory}

\section{Organizational Response Strategies to Institutional Pressure}

Of particular interest to our research is the body of literature that uses organizational theories to explain how firms respond to their environment. As noted by Basu and Palazzo (2008), there has been an emphasis in the literature on the "content of CSR activities" and "neglect of institutional factors that might trigger or shape such activities in the first place." Institutional theory states that the business environment in which a firm operates exerts pressure on the firm. Pressures from these systems elicit different responses as firms seek legitimacy in order to "survive and thrive" in their environment (Scott, 2008). Institutional theory recognizes, however, that organizations are not passive actors and can respond to institutional demands in a variety of ways from conformance to reshaping those pressures (Scott, 2008).

Some CS scholars have invoked institutional theory to explain differences in the approaches firms adopt to address CS. For example, Husted and Allen (2006) found that institutional pressures rather than strategic analysis of social issues and stakeholders could be used to explain the CS practices of multinational companies. Matten and Moon (2008) employed institutional theory to conceptualize why CS differs among countries and how it is changing within countries. Institutional theory has also been used to argue that companies pursue CS in order to gain legitimacy in their organizational field (Hahn \& Scheermesser, 2006). Campbell (2007) used institutional theory to raise attention to broader environmental factors, including the relative health of corporations, the economy, and level of competition, that directly impact a company's CS activities.

While recognizing the work focused on external institutional influences, Basu and Palazzo (2008) suggest that "an alternative and potentially richer description of CS might emerge from studying internal institutional determinants..." Therefore, we will use institutional theory not only as a framework to examine the external drivers that influence an organization's pursuit of sustainability, but the internal drivers as well. In the context of organizational change, institutional theory asserts that "market pressures and managerial capacities" are considered the most important factors in promoting change in an organization (Powell \& DiMaggio, 1991). Managers as institutional actors are the causal agents that have the ability to interpret and reframe demands for the organization (Scott, 2008). In particular, CEOs as "designers of organizations" have characteristics that influence how the organization responds and adapts to change (Scott, 2008). Thus we will attend to the role of top management of each company with respect to sustainability initiatives and offer the following proposition:

\section{P1: Top management will be the dominant force for sustainability initiatives, both as a source of pressure and as the translator of pressure from the external environment.}

Another aspect of institutional theory employed in this study pertains to the response that firms exhibit to institutional demands. Oliver (1991) describes five strategies firms adopt in response to institutional pressures, ranging from passive conformity to active manipulation. Acquiescence refers to adherence, conformity or imitation of actions and practices of the institutional environment. Compromise may occur when a company attempts to placate, negotiate or balance conflicting institutional demands. Firms may also choose to avoid conforming to institutional pressure by concealing nonconformity, escaping the domain that exerts the pressure or buffering the organization from external scrutiny. Firms 
may pursue active resistance to pressures from the environment in the form of defiance by ignoring, challenging or attacking institutional demands. According to Oliver, the most active response a firm may adopt is one of manipulation in which a firm attempts to change, control, or influence the institutional pressures. We assert it would not be rational to expect a firm that has expressed a commitment to sustainability to engage in activities that could be construed as avoiding or defying. In other words, we expect firms that have expressed a commitment to CS to engage in activities that promote sustainability. Therefore, we offer the following proposition:

\section{P2: Firms with an expressed commitment to Corporate Sustainability will demonstrate commitment through strategies of manipulation, compromise and acquiescence in response to institutional forces.}

\section{Organizational Learning Theory}

While institutional theory is used to understand how the environment influences the firm's strategic response to $\mathrm{CS}$, it is not sufficient to explain how companies execute their sustainability strategy. Literature suggests that "the capacity of an organization to learn effectively plays an essential role in sustainability performance" (Crews, 2010). Therefore, we turn to organizational learning theory to gain a better understanding of the characteristics that enable firms to execute a chosen sustainability strategy through specific initiatives.

Organizational learning theory presents the process of change in organizations in terms of two dynamics of learning: "exploitation of old certainties" and "exploration of new possibilities" (March, 1991). March asserts that returns from exploitation of existing capabilities can be achieved with greater certainty, have a shorter time horizon, and are less costly to pursue than the innovations associated with an exploration-based learning approach. Indeed, returns from exploration are uncertain, have a longer time horizon, and are expensive to pursue. While it is understood that exploration and exploitation may compete for resources within a firm, the focus on one type of learning can be to the detriment of the other (Benner \& Tushman, 2003). For example, the literature suggests that a focus on process management activities and practices, as would be expected in a manufacturing firm, may hinder exploratory activities (Benner \& Tushman, 2003). However, if a manufacturing firm has a strong research and development orientation, we would expect this to result in a balancing of efficiency oriented process management activities with innovation-oriented activities. Therefore, we state a third proposition:

\section{P3-a: Manufacturing firms with a strong research and development orientation will execute sustainability initiatives that are both exploitative and exploratory.}

Organizational learning theory also suggests that learning partners are critical dimensions of organizational learning (Slater \& Narver, 1995). Learning partners may be intra-organizational or interorganizational. By acquiring and exploiting knowledge of others, it is argued that "learning alliances allow firms to increase the speed of capability development and minimize uncertainty" (Rothaermel \& Deeds, 2004). Surveys of corporate executives, however, reveal that the primary challenge faced in practice is understanding market demand for sustainability and executing sustainability initiatives (Lacey et al, 2010; Pohle \& Hittner, 2008). This suggests that companies may seek the experience of others to develop and execute CS initiatives. Therefore, we state a fourth proposition:

\section{P3-b: Intra- and inter-organizational learning is a key attribute of firms that successfully embrace sustainability.}

\section{RESEARCH METHODOLOGY}

An exploratory case study approach was used to gather extensive and context-rich data from two companies (Yin, 2009). Specifically, we employed a multiple case study embedded design involving 
sustainability initiatives implemented within each company. The origin and implementation of initiatives was investigated using semi-structured in-depth interviews with senior management and both functional and department heads at each company. Initial interviews with senior management allowed us to identify specific CS initiatives, allowing for in-depth analysis of the initiatives with the individuals responsible for designing and implementing them. All of the participants had either general oversight or specific responsibility for sustainability initiatives. Concepts from institutional theory and organizational learning theory were used to understand how each company pursued sustainability.

\section{Sampling}

A literal replication strategy was applied in which two privately-owned U.S. based manufacturing firms (Company A and Company B) were selected for participation in this study. Both companies have been in business for roughly the same amount of time, both have significant research and development functions, both have an expressed commitment to sustainability, and both see themselves as sustainability leaders within their respective industries.

According to Yin (2009), literal replication occurs in a multiple case study if similar results are predicted. Despite differences in terms of operations and markets served, the companies share commonalities, specifically private ownership, a history of innovation, U.S. domicile, common sector (i.e., manufacturing), and similar operational time spans. Although not a supplier to Company B, Company A makes components for the competitors of Company B. Furthermore, the former Chairman/CEO of Company B worked for many years at a firm started by a former senior manager of Company A. The theory of structural equivalence suggests that actors who share ties may behave similarly (Brass et al, 2004; Vedres and Stark, 2010). Therefore, using the logic of structural equivalence, we expect both companies to respond to similar institutional pressures in a similar manner.

Company A: Founded in 1865, this company began with a single product category and location and grew into a diversified manufacturer of more than 19,000 products with 45 manufacturing plants worldwide and almost 9,000 employees. Throughout its history, ownership of Company A has remained in the hands of the founding family. The grandson of the founder is the current Chairman of the company. Company A has always considered sustainability a cornerstone of its business philosophy and corporate strategy.

Company B: Founded in 1870, this company started as a manufacturer of a single product category with a single location. Still focusing on one product category, Company B operates 21 manufacturing plants in North America with about 2,800 employees. The company is privately owned but has changed ownership a number of times since its inception. Relative to their industry, Company B considers itself an early mover and a leader in sustainability.

\section{Data Collection and Analysis}

Semi-structured interviews were conducted using an interview protocol that was tailored for the employee and his/her role with respect to sustainability. This insured that the researchers followed a systematic approach, but at the same time provided the opportunity to further probe specific areas of interest as the interviews unfolded. There were a total of 14 participants in this study. Four of the participants were from Company A and eight from Company B (See Table 1). To gain a deeper understanding of the business environment in which Company B operates and to confirm data obtained from the company, we also interviewed a representative from one of the industry associations and a senior manager who is responsible for sustainability programs with a competitor. Seven interviews were conducted in face-to-face meetings and six were conducted by telephone. One interview with Company B had five employees present. Three individuals from company A were interviewed twice due to the expanse of their responsibilities in implementation of sustainability initiatives at their firm. Interviews lasted one to two hours. 
TABLE 1

STUDY PARTICIPANTS BY COMPANY

\begin{tabular}{|l|l|}
\hline \multicolumn{1}{|c|}{ Company A } & \multicolumn{1}{c|}{ Company B } \\
\hline Director of Sustainability & Former Chairman/CEO/Investor \\
\hline $\begin{array}{l}\text { Director Energy Development of Affiliated } \\
\text { Company/ Former Vice President of Company A }\end{array}$ & CEO/COO \\
\hline Director of Corporate Environmental & Senior Vice President, Technical Services \\
\hline \multirow{2}{*}{ Product Line Business Manager } & $\begin{array}{l}\text { Senior Director Engineering Development and } \\
\text { Manufacturing Support }\end{array}$ \\
\hline \multirow{2}{*}{} & Director of Engineering \\
\cline { 2 - 2 } & Director of Supplier Quality \\
\cline { 2 - 2 } & Specialty Product Brand Director \\
\cline { 2 - 2 } & Vice President of Sales \\
\cline { 2 - 2 } \\
\hline
\end{tabular}

All interviews were digitally recorded and transcribed, and all but one interview was conducted with at least two researchers present. Three researchers coded the interviews in NVivo. An initial coding scheme was developed after the first interview and then reviewed and modified with each subsequent interview (Charmaz, 2006). The first interview was jointly coded by the three researchers to confirm consistency in interpretation of codes. The second interview was independently coded by each of the three researchers. Superior inter-rater reliability was verified by comparing the separately coded transcripts. The remaining transcripts were divided among the three researchers and coded independently, with follow-up discussions on crucial elements and salient comments made by the interviewees. Codes were aligned with the research questions and queries were executed within NVivo to extract coded text.

Data were analyzed initially to identify similar influences and trends in the motivation and adoption of sustainability initiatives. We then analyzed the data employing two complimentary organizational theories. Institutional theory was employed to assess (1) the source of pressure or motivation that elicits a response from the company and (2) the nature of the response strategy adopted by the company. We then employed concepts from organizational learning theory to analyze specific sustainability initiatives. Here, we focused on learning strategies and learning alliance mechanisms to understand the attributes that drive execution and integration of sustainability initiatives.

\section{RESULTS AND DISCUSSION}

Several themes emerged from the data that illustrate the circumstances and capabilities that enable companies to translate institutional pressures into sustainability initiatives. First, in both companies, it was the owner or Chairman/CEO who created an awareness of and a commitment to sustainability. Second, both companies identified multiple institutional pressures that required attention to sustainability. Third, both companies adopted similar response strategies, either conforming to pressure or actively influencing the environment to reshape the nature of the pressure. Fourth, the sustainability initiatives that resulted entailed both exploitation of current expertise and exploration of new capabilities. And fifth, the dual capabilities to execute both exploitative and exploratory initiatives appeared to be facilitated through intra- and inter-organizational learning alliances. Table 2 in the Appendix presents the sustainability initiatives reported by each company along with the corresponding source of pressure, response strategy, learning strategy and learning alliance, as well as relevant quotations from participants. Table $2 \mathrm{~A}$ presents 
the initiatives from Company A and Table 2B presents the initiatives from Company B.

\section{RQ1: What are the dominant sources of institutional pressure for sustainability in the firm?}

Both companies in this study identified myriad but similar sources of pressure that directed their attention to the issue of sustainability, and both companies demonstrated a commitment to address that pressure. Both companies viewed the threat of regulatory or legislative action, actions of competitors, and demands from customers as sources of pressure for more sustainable practices. Furthermore, Company A reported engagement by NGO's and activist groups as a source of pressure for sustainability. However, one key theme emerged: the leader of the company was the primary catalyst. In both cases, it was the person at the helm of the company that introduced and ensured that sustainability became an integral part of the business strategy and that resources were directed to the effort. Reflecting on the role of the leader, an executive from Company A shared these thoughts: "[I]n all sustainability cultures of which I'm aware and have had a chance to look at, it has to start at the top company organization. Neither you nor I, no matter how passionate and how much we believe in sustainability, can force it into a company. It has to start at the C-level...there had to be some compelling event that someone at the C-level said, 'Aha, here's something that fits with us or something that we need to do as we move forward."

For Company A, terms such as "sustainability" and "measuring the corporate footprint" are new expressions for existing practices in which they have been engaged for decades. Company A began focusing on water, energy, and environmental conservation in the 1930's. The family that founded, owns and operates Company A has a reputation for being careful with resources and good stewards of nature. Members of the family also serve in leadership roles with environmental organizations. An executive from the company discussed the family's influence in terms of the "DNA of the family" which made environmental sustainability a core value of the company. The family meets a couple of times a year with the Director of Sustainability who describes their support as positive and encouraging. One executive at the company recounted a conversation with the Chairman about reductions in energy use in terms of monetary savings. The executive was reminded by the Chairman that energy reduction must not be measured in terms of cost saying, "I don't care about the cost. That can be impacted by world events, regulators, government; you've always got to measure actual consumption." It is that type of authentic commitment from the Chairman, according to an executive at Company A, that makes the pursuit of sustainability "an easy path" for the company.

As with Company A, the pursuit of sustainability for Company B originated at the top. In 2000, a new Chairman/CEO introduced a commitment to sustainability that was driven by a personal philosophy of environmental stewardship reinforced by years of experience working with a leader in corporate sustainability in another industry. According to one executive at the company, “...we've always been a company focused on quality, but sustainability was never really a focus until [the former Chairman/CEO] came here and said we're going to make it a focus." The former Chairman/CEO infused a sense of responsibility in the company and "declared that the landfill is the enemy" through the introduction of programs focused on waste reduction and performance metrics and compensation tied to the results. Similar to Company A, the commitment from the Chairman makes the path to sustainability an easy one. The influence of this individual was present even after his departure in 2008. As one senior manager described it, "It's all about the culture and . . one of the things he did is to help create the foundation for the company to continue to grow upon. Without him, we would not be here."

In a business environment where the pressure to pursue sustainability originates from many different sources, we observed in our two cases that the strongest pressure comes from the top of the company. Thus, P1 is supported. Pressure from the top appears to increase the awareness and responsiveness of the company to other demands for sustainability practices. The role of the owner or CEO/Chairman as the causal agent promoting change in the form of sustainability is consistent with institutional theory. While overall leadership of sustainability starts at the top of the organization and ultimately determines the company's allocation of resources to CS, it does not fully explain how specific sustainability initiatives arise. 


\section{RQ2: What are the primary response strategies that firm's adopt to address institutional pressures for sustainability?}

Our data reveal that both companies addressed the sustainability challenge by adopting two of the five strategies for responding to institutional pressures that Oliver (1991) describes: acquiescence (conforming to institutional pressures) and manipulation (re-shaping the environment). Our findings did not reveal use of the other three strategies described by Oliver: compromise, avoid and defy. Therefore, our second proposition (P2), Firms with an expressed commitment to Corporate Sustainability will demonstrate commitment through strategies of manipulation, compromise and acquiescence in response to institutional forces, was only partially supported.

A strategy of acquiescence was adopted in response to three primary sources of pressure: (1) pressure for more efficient production and use of resources from the Chairman/CEO (Companies A and B), (2) customer demand for sustainable products (Companies A and B) and (3) market demand for visibility with regards to sustainability practices in order to protect a competitive position (Company A). In the face of these pressures, both companies chose to comply with the demands.

Both companies instituted production-focused initiatives in the form of 'zero waste' programs in response to cost, resource and landfill-use reduction goals. In the case of Company A, the founding family's influence has been a key driver of production related initiatives. Company A has had formal environmental policies and environmental engineers since the 1950's. In recent years, the focus has expanded to include identifying and testing alternative energy sources for use in production. As one senior manager stated, "reducing our footprint has been a key for the company forever." These sustainability initiatives have netted substantial results. Company A claims to have reduced its environmental impact by over $50 \%$ in the last $12-15$ years.

In the case of Company $\mathrm{B}$, the zero waste initiative was introduced by the former Chairman/CEO, who brought a lifelong passion for the environment and experience with successful sustainability initiatives learned from a leader in the adoption of corporate sustainability. At the time the former Chairman/CEO assumed leadership, Company B was facing financial difficulties. The zero waste initiative was instituted to solve two problems, one financial and the other environmental. The former Chairman/CEO identified $\$ 70$ million lost in the form of production waste and "declared the landfill the enemy." The zero waste initiative remains an important practice in all manufacturing plants of Company $\mathrm{B}$ and zero waste goals are incorporated in the compensation and incentive plans for plant employees.

Company B also shared multiple instances in which customer demand drove development of sustainable products. For example, the company used focus groups to identify health concerns that served as the impetus behind an innovative product development. Unfortunately, as the company later learned, customers were not willing to pay the higher cost or adopt new techniques for maintenance of the new product. This product was subsequently modified to address environmental and economic concerns for a specific market segment. The modified product is gaining traction in a broader market previously not served by the company.

Company A acquiesced to market pressure for visibility around its sustainability practices, both to benefit customers and for competitive reasons, when it created the position of Director of Sustainability. According to one Company A executive, this was not an easy change for a company that historically valued privacy. The executive recalls: "[W]e challenged [the Chairman] to become more visible around sustainability...I didn't want to lose market share...we've got to talk about what we are doing around being a green company." The company now posts and updates information on environmental performance to their website every 30-90 days and actively educates the markets on its sustainability practices through participation in industry panels and professional forums.

Acting on competitive pressures that cause uncertainty in the market and create an unfair advantage for competitors, the companies in our study responded by exerting influence and control to reshape the nature of the institutional demands. Both companies reported 'greenwashing,' "the practice of making an unsubstantiated or misleading claim about the environmental benefits of a product," as a major competitive threat (SearchCRM/TechTarget, 2011). 
A senior manager from Company A explained that in every product category, there are competitors who are "honorable" and there are those "who stretch the facts." As a consequence, customers are seeking guidelines that would enable them to more accurately weigh one product against another in terms of sustainability. Company A responded to this threat and the market confusion it causes by co-founding and assuming leadership positions in several professional organizations and industry associations focused on setting sustainability standards. Actively supporting these organizations allow the firms to have a voice in developing industry standards, and motivating other industry firms to work together in educating the consumer.

Executives at both companies recognize that participation in setting product standards also provides the company with an advantage and an opportunity to shape emerging standards. "[W]e came to the realization," one Company A executive explained, "if we did not get involved and take a leadership role, that in many cases standards and organizations are going to become self-serving by some of the people versus leading edge."

Company B is similarly working within its industry associations to develop standards and combat greenwashing. A senior manager from Company B describes an uneven competitive environment: “...these smaller companies are not being truthful...we're a big billion dollar company and my legal department would make me substantiate my claims, whereas some of the these little guys would say I'm $100 \%$ natural... [and] it wasn't true...I wasn't getting a dealer to buy my product because I was being honest, and then the little guy was being dishonest and he was getting the business..."

Paradoxically, Company B learned that while customers were enticed or confused by false claims from competitors, they were not responsive to negative selling from Company B to set the record straight. Therefore, Company B responded by assuming leadership roles within its industry associations to develop uniformity in product labeling and definitions of environmental attributes of products.

The companies we studied also responded to the threat of regulation through a strategy of manipulation by engaging with regulators in the development of policies. Both companies complied with existing regulations, in other words acquiesced to regulatory pressure. The more interesting theme emerged around their efforts to proactively influence regulation. Both companies attempted to be ahead of regulation in an effort to, as one Company B manager explained, "be part of rule making so that we end up with rules that are appropriate for industry, things we can live with, things that are manageable."

Company A, for example, helped one federal agency shape regulation around waste water treatment that was based on the company's existing practices. The federal agency actually approached the Company $\mathrm{A}$, as it was well-known that their practices were over and above other manufacturing companies at the time. Company B, responding to the threat of future regulation of the end of life disposal of the products it manufactures, began piloting technology for recycling and working to develop an economically viable business model for the collection and recycling by third parties. The hope is to come up with a better solution for the end of life problem than the potential legislative solution that would ban the product from landfills.

An understanding of institutional demands is only part of the story of how sustainability initiatives are executed. Once a company determines its response strategy, it then needs to determine how to execute the sustainability initiative. To answer this we turn to organizational learning theory.

\section{RQ3: What organizational learning strategies do firms adopt in the execution of sustainability initiatives?}

\section{Learning Strategies: Exploitation vs. Exploration}

Our findings show that the companies we studied possess the ability to execute sustainability initiatives opportunistically and concurrently through strategies of exploitation and exploration. This dual capability appears to expand the types of initiatives the company can execute in response to sustainability challenges, allowing the company to pursue a diverse agenda of initiatives. For the two companies we examined, both production management experience and R\&D expertise appeared to be important in the execution of sustainability initiatives. Thus, proposition P3-a, manufacturing firms with a strong research 
and development orientation will execute sustainability initiatives that are both exploitative and exploratory was supported.

Production-oriented initiatives were the first sustainability initiatives adopted by both companies. An executive from Company A traces correspondence pertaining to sustainability initiatives back to the " 1930 's or '40's where the engineers of our plant were responding to the founders on issues of water, energy conservation, and those kind of things." The pursuit of sustainability at Company B began with the 'zero waste' initiative. Both companies point to immediate results in both environmental terms and costs savings as benefits of production-focused sustainability initiatives. The benefits of exploitation outlined by March (1991) suggest that production-focused sustainability initiatives are a less risky endeavor for companies as they begin to embrace sustainability.

Additional examples of exploitation were found in initiatives involving collaboration and alliances. Both companies are involved with industry associations and leverage their existing capabilities and expertise to influence industry sustainability practices and standardization, such as with the pursuit of standardized product labels by Company B. Company A exploited their expertise in waste water treatment when they collaborated with federal regulators to establish new policies in this area. They also leveraged their expertise in sustainability by co-founding professional associations focused on sustainability, as noted above.

Company B was also able to exploit existing unsuccessful products by engaging new partners. In one initiative, Company B partnered with a major retailer and 'eco-expert' to create a new distribution channel to promote their eco-friendly products, that previously had not gained traction in the market. The retailer had approached the manufacturer due to their reputation as a market leader, assuming their reputation would provide a positive association to customers as the products in the sustainability space were gaining traction. They also worked with a prospective customer to modify a sustainability product that had been abandoned, and as a result, found a new market for the modified product.

March's (1991) assertion that exploration is a greater risk and more costly proposition for an organization may explain why the companies in our study disclosed fewer initiatives in this category. As one senior manager at Company B explained, "Innovation has to get to the point where doing the right thing is a profitable venture." When it comes to sustainability, we found that both companies were willing to assume the risk associated with exploration, perhaps because of their commitment to R\&D which allows them to pursue sustainability at an advanced level as they are aware of the potential benefits and returns of exploration. Company A reported exploratory initiatives that were product and production focused. One example is an initiative focused on the exploration of alternative energy sources: "We're spending a lot of time in understanding alternative energy and how do we adopt alternatives to fossil fuel...we've got another location starting up...if that works out the way the others have, I think you'll see us go to a major use of biogas replacing natural gas across the company, around the world."

Another example involves a response to the growing concern from environmentalists over a material used in their products. Company A proactively developed a material that is better for the environment, less expensive and has better performance attributes.

Company B learned a costly lesson when one of their exploratory sustainability initiatives resulted in a failed product innovation: do not assume that customers are willing to pay a premium for sustainability. However, this has not deterred the company from pursuing other exploratory initiatives. They are currently piloting recycling technology and developing a new material that will reduce product returns; both initiatives are in response to the growing concern over disposal of their products.

The dual capability exhibited by both companies in executing initiatives is facilitated by an open approach to surfacing CS initiatives that allows ideas to come from different departments, encourages collaboration, and gives managers the authority to allocate resources. According to one Company B executive, ideas "come from the bottom up. They come from the top down. They come left and right." Another senior manager in the company explained that although the CEO sets the overall objectives of the company, each functional channel has the autonomy to determine how to deliver that strategy. The CEO of Company B concurred stating that his job was to set the "standards" and the "tone" but he relied on marketing and engineering to figure out how to execute. Similarly, a Company A executive explained that 
they execute sustainability initiatives as follows: "While we have centralized functions, we have a lot of decentralized functions... we just go to whoever we need to no matter what structure they're in and get them involved to help us do what needs to be done."

\section{Learning Alliances}

Supporting the dual capabilities of exploitation and exploration is a philosophy that "all of us are smarter than one of us" which was expressed through alliances and partnerships within organizations as well as between organizations and industries. These findings are consistent with organizational learning theory and the integrated framework conceptualized by Holmqvist (2004) in which "exploitation is interlaced with exploration within and between organizations" and supports our fourth proposition (P3-b): Intra- and inter-organizational learning is a key attribute of firms that successfully embrace sustainability. A senior manager of Company B best explained the benefit of this philosophy as follows: "Once you let your guard down and accept the fact that you don't know everything, then you open your mind to the wealth of opportunity."

Through alliances, the expertise in one organization can serve as a catalyst for learning in another organization. One such example is the recycling initiative being implemented by Company B. A senior engineer with the company explained, "...we did look to other industries a lot in fact. That was a good idea because it ended up giving us a leg into what we hope would be a solution." In another example, a Company B manager explained how they used the alliance with a major retailer and an eco-expert to educate their sales force on sustainable products. The brand director described the results as follows: “...our sales guys felt more confident showing it [natural product line] to more retail channels...And then they started showing it to other dealers and their dealers kept saying 'I'm hearing a demand for it too. I need to have that on my floor.",

Furthermore, Company B's 'zero waste' goals, which are incorporated in the compensation program for its plants, led one employee to identify a source of waste from the packaging of materials. The plant employee alerted a manager at the company and together they collaborated with the supplier to develop a solution to reduce the waste of materials and save a great deal of money.

Learning alliances also extend to organizations such as regulatory bodies and NGO's, once considered adversaries. One Company A executive explained: "II]f you go back and look at corporate paradigms twenty years ago there was a paradigm that you don't want to be involved with an NGO because they'll create problems. They start poking around in your company and then all of a sudden you're exposed for everything that you do. I think that paradigm was really changed over the last 5 to 10 years... we're actively seeking out those NGOs that have good insight..."

The pursuit of sustainability also entails collaboration with another set of potential adversaries, the firm's competitors. Both companies provided financial support and technical expertise to industry associations in an effort to establish industry sustainability standards. According to one Company A manager: "[W]e've realized that sharing is not all bad, which opened the door for us to start being more involved in some of these industry or technology or directional type movements."

\section{CONTRIBUTION AND IMPLICATIONS}

The objective in this study was to understand how firms shape their response to institutional pressures for sustainability through implementing initiatives. We studied this phenomenon in terms of (1) the institutional pressures to pursue sustainability that firms encounter, (2) the strategies firms adopt in response to the pressures for sustainability and (3) the organizational learning strategies that facilitate the execution of initiatives.

Our data reveal that sustainability initiatives represent responses to a variety of demands from the business environment. Of particular importance is the role of executive leadership. In both companies we studied, it was the owner or Chairman/CEO who instilled an awareness of and commitment to sustainability. They communicated their vision and goals and allocated resources. It was through the leadership from the top that the companies embraced sustainability as a mission. 
We also found that the type of pressure from the environment influenced the response strategy adopted by the companies. Using Oliver's (1991) typology for response strategies to institutional pressures, the companies in our study exhibited two responses: acquiescing to demands and manipulating the environment. The companies chose to comply or conform when demands were from the Chairman/CEO, from customers and when they entailed a call for greater visibility around sustainability practices. Conversely, these companies chose to exert control and manipulate the environment when faced with competitive and regulatory threats in an effort to reduce uncertainty and put them in a more advantageous position.

Both companies were able to simultaneously execute initiatives that exploited existing expertise as well as initiatives that explored new opportunities. We suggest that this dual capability is facilitated by the combination of production management and $\mathrm{R} \& \mathrm{D}$ expertise with an open approach to surfacing CS initiatives that enables the companies to pursue a diverse sustainability agenda. Our findings also showed that alliances and collaboration were critical to the execution of sustainability initiatives. The organizational boundaries were permeable allowing for intra- and inter-organizational learning to support initiatives, even if it included organizations typically considered adversaries.

Although the findings from case studies of two companies would not be considered generalizable, our results provide insights that may inform practice for organizations that seek to establish or expand their sustainability practice. First, individuals at the top of an organization must communicate a commitment to the pursuit of sustainability and demonstrate that commitment through allocation of resources. Second, the organizational structure should employ an open approach to surfacing CS initiatives in order to allow those functions closest to the source of pressure from the business environment to initiate the response and tailor the response to the nature of the pressure. Third, organizations should seek intra- and interorganizational alliances to support the execution of sustainability initiatives.

The implications for future research are broad as this study explored a number of theories and concepts. The model conceptualized by Oliver (1991) may be further used to study whether specific attributes of institutional pressure predict the response strategy a company is likely to adopt. Another opportunity arises in the study of the organizational structure and the resulting effect on the diversity of sustainability initiatives pursued and organizational alliances that are developed. For example, would a more centralized sustainability function in an organization result in less diverse initiatives and fewer alliances? Finally, a comparison of sustainability initiatives in terms of institutional pressures and organizational learning attributes across industries or sectors may provide additional insights helpful to executives pursuing corporate sustainability.

\section{REFERENCES}

Basu, K., \& Palazzo, G. (2008). Corporate Social Responsibility: A Process Model of Sensemaking. Academy of Management Review, 33, (1), 122-136.

Benner, M. J., \& Tushman, M. L. (2003). Exploitation, Exploration, and Process Management: The Productivity Dilemma Revisited. Academy of Management Review, 28, (2), 238-256.

Campbell, J. L. (2007). Why Would Corporations Behave In Socially Responsible Ways? An Institutional Theory of Corporate Social Responsibility. Academy of Management Review, 32, (3), 946-967.

Carroll, A. B. (1999). Corporate Social Responsibility. Business \& Society, 38, (3), 268.

Charmaz, K. (2006). Constructing Grounded Theory A Practical Guide Through Qualitative Analysis, Los Angeles: Sage Publications, Inc.

Crews, D. E. (2010). Strategies for Implementing Sustainability: Five Leadership Challenges. SAM Advanced Management Journal, Spring, 15-21. 
Haberberg, A., Gander, J., Rieple, A., Juan-Ignacio, M.-C., \& Helm, C. (2007). Patterns in the Adoption of Corporate Social Responsibility Practices. Corporate Responsibility Research Conference, University of Leeds.

Hahn, T., \& Scheermesser, M. (2006). Approaches to Corporate Sustainability Among German companies. Corporate Social Responsibility \& Environmental Management, 13, (3), 150-165.

Holmqvist, M. (2004). Experiential Learning Processes of Exploitation and Exploration Within and Between Organizations: An Empirical Study of Product Development. Organization Science, 15, (1), 7081.

Husted, B. W., \& Allen, D. B. (2006). Corporate Social Responsibility in the Multinational Enterprise: Strategic and Institutional Approaches. Journal of International Business Studies, 37, (6), 838-849.

Kaynak, H., \& Montiel, I. (2009). The Relationship between Sustainable Supply Chain Management and Sustainable Performance: An Integrated Framework. Academy of Management Proceedings, 1-6.

KPMG International Survey of Corporate Social Responsibility Reporting 2008 (2008). Amsterdam.

Lacy, P., Cooper, T., Hayward, R., \& Neuberger, L. (2010). A New Era of Sustainability in Accenture. UN Global Compact - Accenture CEO Study, UN Global Compact - Accenture.

Lockett, A., Moon, J., \& Visser, W. (2006). Corporate Social Responsibility in Management Research: Focus, Nature, Salience and Sources of Influence. Journal of Management Studies, 43, (1), 115-136.

March, J. G. (1991). Exploration and Exploitation in Organizational Learning. Organization Science, 2, (1), 71-87.

Matten, D., \& Moon, J. (2008). "Implicit" and "Explicit" CSR: A Conceptual Framework for a Comparative Understanding of Corporate Social Responsibility. Academy of Management Review, 33, (2), 404-424.

McWilliams, A., Siegel, D. S., \& Wright, P. M. (2006). Corporate Social Responsibility: Strategic Implications. Journal of Management Studies, 43, (1), 1-18.

Oliver, C. (1991). Strategic Responses to Institutional Processes. Academy of Management Review, 16, (1), 145-179.

Pohle, G., \& Hittner, J. (2008). Attaining Sustainable Growth through Corporate Social Responsibility. In I. G. B. Services (Ed.), Corporate Social Responsibility: 1-17. Somers, NY: IBM.

Porter, M. E., \& Kramer, M. R. (2006). Strategy \& Society: The Link between Competitive Advantage and Corporate Social Responsibility. Harvard Business Review, 84, (12), 78-92.

Powell, W. W., \& DiMaggio, P. J. (Eds.). (1991). The New Institutionalism in Organizational Analysis. Chicago: The University of Chicago Press.

Quinn, L., \& Dalton, M. (2009). Leading for Sustainability: Implementing the Tasks of Leadership. Corporate Governance, 9, (1), 21-38. 
Rothaermel, F. T., \& Deeds, D. L. (2004). Exploration and Exploitation Alliances in Biotechnology: A System of New Product Development. Strategic Management Journal, 25, (3), 201-221.

Scott, W. R. (2008). Institutions and Organizations Ideas and Interests. Los Angeles: Sage Publications, Inc.

SearchCRM/TechTarget. Retrieved October 10, 2011 from the SearchCRM wiki: http://searchcrm.techtarget.com/definition/greenwashing.

Slater, S. F., \& Narver, J. C. (1995). Market Orientation and the Learning Organization. Journal of Marketing, 59, (3), 63.

van Marrewijk, M. (2003). Concepts and Definitions of CSR and Corporate Sustainability: Between Agency and Communion. Journal of Business Ethics, 44, (2/3), 95-105.

Yin, R. K. (2009). Case Study Research Design and Methods. Los Angeles: Sage Publications, Inc.

\section{APPENDIX}

TABLE 2A

SUSTAINABILITY INITIATIVES REPORTED BY COMPANY A

\begin{tabular}{|c|c|c|c|c|c|}
\hline $\begin{array}{l}\text { Sustainability } \\
\text { Initiative }\end{array}$ & $\begin{array}{l}\text { Source of } \\
\text { Pressure }\end{array}$ & $\begin{array}{l}\text { Response } \\
\text { Strategy }\end{array}$ & $\begin{array}{l}\text { Learning } \\
\text { Strategy }\end{array}$ & $\begin{array}{l}\text { Learning } \\
\text { Alliance }\end{array}$ & Quotes \\
\hline $\begin{array}{l}\text { Collaboration } \\
\text { with } \\
\text { government } \\
\text { agency to } \\
\text { develop } \\
\text { regulations }\end{array}$ & Regulatory & Manipulate & Exploitation & $\begin{array}{c}\text { Inter- } \\
\text { organizational }\end{array}$ & $\begin{array}{l}\text { "Even before the EPA was founded, we } \\
\text { had waste water treatment standards in } \\
\text { the company that actually the EPA } \\
\text { standards were based upon... We're } \\
\text { trying to be ahead of the regulation." }\end{array}$ \\
\hline $\begin{array}{l}\text { Co-founded } \\
\text { industry and } \\
\text { professional } \\
\text { organizations } \\
\text { focused on } \\
\text { sustainability } \\
\text { certification } \\
\text { and standards }\end{array}$ & $\begin{array}{c}\text { Regulatory } \\
\text { Competition } \\
\text { Customer }\end{array}$ & Manipulate & Exploitation & $\begin{array}{c}\text { Inter- } \\
\text { organizational }\end{array}$ & $\begin{array}{l}\text { "And as we started looking at } \\
\text { sustainability and as we started looking } \\
\text { at standards, we came to the } \\
\text { realization, if we did not get involved } \\
\text { and take a leadership role, that in many } \\
\text { cases standards and organizations are } \\
\text { going to become self-serving by some } \\
\text { of the people versus leading edge." }\end{array}$ \\
\hline $\begin{array}{l}\text { Established } \\
\text { position of } \\
\text { Director of } \\
\text { Sustainability }\end{array}$ & Competition & Acquiesce & Exploitation & $\begin{array}{c}\text { Intra- } \\
\text { organizational }\end{array}$ & $\begin{array}{l}\text { "...we challenged [the owner] to } \\
\text { become more visible around } \\
\text { sustainability...I didn't want to lose } \\
\text { market share...we've got to talk about } \\
\text { what we are doing to be a green } \\
\text { company." }\end{array}$ \\
\hline $\begin{array}{l}\text { Zero waste in } \\
\text { manufacturing }\end{array}$ & $\begin{array}{c}\text { Chairman / } \\
\text { CEO }\end{array}$ & Acquiesce & Exploitation & $\begin{array}{c}\text { Intra- } \\
\text { organizational }\end{array}$ & $\begin{array}{l}\text { "I have correspondence from...I don't } \\
\text { remember the first one, but the ' } 30 \text { 's or } \\
\text { ' } 40 \text { s where the plant engineers were } \\
\text { responding to issues on water, energy } \\
\text { conservation, and those kind of things." } \\
\text { "Globally in the corporation we've } \\
\text { reduced our environmental impact by } \\
\text { over } 50 \% \text { in the last } 12 \text { to } 15 \text { years. } \\
\text { We've been meeting and exceeding } \\
\text { those goals. We keep finding things to } \\
\text { do better." }\end{array}$ \\
\hline
\end{tabular}




\begin{tabular}{|c|c|c|c|c|c|}
\hline $\begin{array}{l}\text { Energy use } \\
\text { reduction and } \\
\text { alternative } \\
\text { energy } \\
\text { development } \\
\text { for } \\
\text { manufacturing }\end{array}$ & $\begin{array}{c}\text { Chairman / } \\
\text { CEO }\end{array}$ & Acquiesce & Exploration & $\begin{array}{c}\text { Intra- } \\
\text { organizational }\end{array}$ & $\begin{array}{l}\text { "We're spending a lot of time in } \\
\text { understanding alternative energy and } \\
\text { how do we adopt alternatives to fossil } \\
\text { fuel...we've got another location } \\
\text { starting up...if that works out the way } \\
\text { the others have, I think you'll see us go } \\
\text { to a major use of biogas replacing } \\
\text { natural gas across the company around } \\
\text { the world." }\end{array}$ \\
\hline $\begin{array}{l}\text { Waste } \\
\text { reduction in } \\
\text { product design } \\
\text { and voluntary } \\
\text { elimination of } \\
\text { potentially } \\
\text { harmful } \\
\text { chemicals and } \\
\text { underground } \\
\text { storage tanks }\end{array}$ & $\begin{array}{l}\text { Chairman / } \\
\text { CEO Activist }\end{array}$ & Acquiesce & Exploitation & $\begin{array}{c}\text { Intra- } \\
\text { organizational }\end{array}$ & $\begin{array}{l}\text { "Well luckily, the four chemicals that } \\
\text { they're looking at we removed from the } \\
\text { company } 20 \text { years ago." } \\
\text { "...in 1988, we excavated underground } \\
\text { storage tanks with no regulatory } \\
\text { requirement because the CEO said that } \\
\text { "We need them out because nothing } \\
\text { good is going to come of this in the } \\
\text { future." }\end{array}$ \\
\hline $\begin{array}{l}\text { Innovation } \\
\text { driven by } \\
\text { environmental } \\
\text { concerns over } \\
\text { a material } \\
\text { widely used in } \\
\text { product } \\
\text { offering }\end{array}$ & Activist & Acquiesce & Exploitation & $\begin{array}{c}\text { Inter- } \\
\text { organizational }\end{array}$ & $\begin{array}{l}\text { "We would never have started down } \\
\text { that path had we not started getting } \\
\text { concerns about [product]..." "[I]f you } \\
\text { go back and look at corporate } \\
\text { paradigms twenty years ago there was a } \\
\text { paradigm that you don't want to be } \\
\text { involved with an NGO because they'll } \\
\text { create problems. They start poking } \\
\text { around in your company and then all of } \\
\text { a sudden you're exposed for everything } \\
\text { that you do. I think that paradigm was } \\
\text { really changed over the last } 5 \text { to } 10 \\
\text { years...we're actively seeking out } \\
\text { those NGOs that have good insight..." }\end{array}$ \\
\hline
\end{tabular}

TABLE 2B

SUSTAINABILITY INITIATIVES REPORTED BY COMPANY B

\begin{tabular}{|c|c|c|c|c|c|}
\hline $\begin{array}{l}\text { Sustainability } \\
\text { Initiative }\end{array}$ & $\begin{array}{l}\text { Source of } \\
\text { Pressure }\end{array}$ & $\begin{array}{l}\text { Response } \\
\text { Strategy }\end{array}$ & $\begin{array}{l}\text { Learning } \\
\text { Strategy }\end{array}$ & $\begin{array}{l}\text { Learning } \\
\text { Alliance }\end{array}$ & Quotes \\
\hline $\begin{array}{l}\text { Collaboration } \\
\text { with industry } \\
\text { associations to } \\
\text { develop } \\
\text { standards for } \\
\text { product labels } \\
\text { and common } \\
\text { terminology } \\
\text { for } \\
\text { environmental } \\
\text { attributes }\end{array}$ & $\begin{array}{l}\text { Competition } \\
\text { Customer }\end{array}$ & Manipulate & Exploitation & $\begin{array}{c}\text { Inter- } \\
\text { organizational }\end{array}$ & $\begin{array}{c}\text { "There's a lot of green washing that's } \\
\text { going on in consumer goods generally } \\
\text { but also in the [product] area, so we're } \\
\text { looking at how can we try to create or } \\
\text { hone in on acceptable consistent terms, } \\
\text { should we adopt as an industry some of } \\
\text { sort of a green label. Those are the } \\
\text { things that we're looking at very } \\
\text { intensively." }\end{array}$ \\
\hline
\end{tabular}




\begin{tabular}{|c|c|c|c|c|c|}
\hline $\begin{array}{l}\text { Collaboration } \\
\text { with industry } \\
\text { associations on } \\
\text { end of life } \\
\text { disposal } \\
\text { solutions } \\
\text { through } \\
\text { sponsorship of } \\
\text { product } \\
\text { recycling pilot } \\
\text { program }\end{array}$ & Regulatory & Manipulate & Exploration & $\begin{array}{c}\text { Inter- } \\
\text { organizational }\end{array}$ & $\begin{array}{l}\text { “...we're at a point in the road here } \\
\text { where the problem exists with [product] } \\
\text { disposal. And, we're either going to } \\
\text { solve it as an industry in advance of } \\
\text { being regulated or government will } \\
\text { force us to solve the problem.” }\end{array}$ \\
\hline $\begin{array}{l}\text { Zero waste in } \\
\text { manufacturing }\end{array}$ & $\begin{array}{c}\text { Chairman/CE } \\
\mathrm{O}\end{array}$ & Acquiesce & Exploitation & $\begin{array}{l}\text { Intra- } \\
\text { organizational } \\
\quad \& \text { Inter- } \\
\text { organizational }\end{array}$ & $\begin{array}{l}\text { "Because anything that's waste is } \\
\text { something that we pay for, that our } \\
\text { customer isn't willing to pay for." }\end{array}$ \\
\hline $\begin{array}{l}\text { Product } \\
\text { innovation to } \\
\text { address health } \\
\text { concerns but } \\
\text { lacked market } \\
\text { acceptance }\end{array}$ & Customer & $\begin{array}{l}\text { Acquiesce/ } \\
\text { Manipulate }\end{array}$ & Exploration & $\begin{array}{l}\text { Inter- } \\
\text { organizational } \\
\quad \& \text { Intra- } \\
\text { organizational }\end{array}$ & $\begin{array}{l}\text { "[T]he idea was to try to come up with } \\
\text { another way to keep those products out } \\
\text { of the landfill, deal with the health } \\
\text { issues..." "And that was one of the } \\
\text { things they did with focus groups, and } \\
\text { almost all consumers thought it was a } \\
\text { great idea but asked if they were willing } \\
\text { to go ahead and pay a premium to do } \\
\text { that, virtually all of them said no." }\end{array}$ \\
\hline $\begin{array}{l}\text { Development } \\
\text { of sustainable } \\
\text { product from } \\
\text { modification of } \\
\text { failed } \\
\text { innovation }\end{array}$ & Customer & Acquiesce & Exploitation & $\begin{array}{l}\text { Inter- } \\
\text { organizational } \\
\quad \& \text { Intra- } \\
\text { organizational }\end{array}$ & $\begin{array}{c}\text { "[W]e had to find a way to differentiate } \\
\text { ourselves and break through the } \\
\text { hospitality business because at that point } \\
\text { in time we didn't have much market } \\
\text { share." }\end{array}$ \\
\hline $\begin{array}{l}\text { Alliance to sell } \\
\text { new product } \\
\text { line with } \\
\text { positive } \\
\text { environmental } \\
\text { attributes }\end{array}$ & Customer & Acquiesce & Exploitation & $\begin{array}{c}\text { Inter- } \\
\text { organizational }\end{array}$ & $\begin{array}{l}\text { “...our sales force... had no } \\
\text { understanding of the green category, no } \\
\text { understanding of why selling a [natural } \\
\text { product line] would be of interest to the } \\
\text { customer... For the first year it } \\
\text { struggled...nobody wanted to pitch } \\
\text { it...But when we signed on with [the } \\
\text { alliance partners]...that's when the brand } \\
\text { really took off." "What's great is I think } \\
\text { our sales guys felt more confident } \\
\text { showing it to more retail channels...And } \\
\text { then they started showing it to their } \\
\text { dealers and their dealers kept saying, } \\
\text { 'I'm hearing a demand for it too."' }\end{array}$ \\
\hline $\begin{array}{l}\text { Product } \\
\text { innovation to } \\
\text { reduce returns } \\
\text { and address } \\
\text { one aspect of } \\
\text { disposal issue }\end{array}$ & $\begin{array}{l}\text { Regulatory } \\
\text { Customer }\end{array}$ & Manipulate & Exploration & $\begin{array}{c}\text { Intra- } \\
\text { organizational }\end{array}$ & $\begin{array}{c}\text { "So, in our attempt to reduce the return } \\
\text { rate, create a sustainable product...make } \\
\text { the sale, we're spending a little more } \\
\text { money..." }\end{array}$ \\
\hline
\end{tabular}

